University of Nebraska - Lincoln

DigitalCommons@University of Nebraska - Lincoln

1992

\title{
Introduction to Special Section on the Cajon Pass Scientific Drilling Project
}

Mark D. Zoback

Stanford University, zoback@stanford.edu

Arthur H. Lachenbruch

U.S. Geological Survey

Follow this and additional works at: https://digitalcommons.unl.edu/usgsstaffpub

Part of the Earth Sciences Commons

Zoback, Mark D. and Lachenbruch, Arthur H., "Introduction to Special Section on the Cajon Pass Scientific Drilling Project" (1992). USGS Staff -- Published Research. 463.

https://digitalcommons.unl.edu/usgsstaffpub/463

This Article is brought to you for free and open access by the US Geological Survey at DigitalCommons@University of Nebraska - Lincoln. It has been accepted for inclusion in USGS Staff -- Published Research by an authorized administrator of DigitalCommons@University of Nebraska - Lincoln. 


\title{
Introduction to Special Section on the Cajon Pass Scientific Drilling Project
}

\author{
MARK D. ZOBACK \\ Department of Geophysics, Stanford University, Stanford, California
}

ARThur H. LachenBruch

U.S. Geological Survey, Menlo Park, California

Over the past few decades a generally accepted conceptual model for the thermomechanics of the San Andreas fault was based on three factors believed to have been supported by observation: (1) maximum horizontal shear stress increases with depth in the crust at the rate of $7-8 \mathrm{MPa} / \mathrm{km}$ (as indicated by measurements in relatively shallow boreholes), roughly the same rate of shear stress increase as in other regions [e.g., McGarr et al., 1982], (2) the maximum horizontal stress direction in the vicinity of the fault was oriented at about $30^{\circ}-45^{\circ}$ to its strike (as indicated by the predominance of right-lateral strike-slip earthquakes along it), and (3) there is no detectable frictional heat generated by the San Andreas (as implied by heat flow observations in numerous shallow boreholes both near and far from the fault along the length of the San Andreas system). Assuming that laboratory-derived coefficients of friction in the range 0.6-1.0 [e.g., Byerlee, 1978] are applicable to all faults in the crust (sometimes referred to as "Byerlee's law" [after Brace and Kohlstedt, 1980]) and that approximately hydrostatic fluid pressure exists at depth, it is straightforward to show that while the second observation is related directly to the first, the stress state they imply at depth would result in a conspicuous heat flow anomaly; a direct contradiction of observation 3. This contradiction has come to be known as the San Andreas stress/heat flow paradox.

The basic question has been whether the average shear stress on the seismogenic portion of the fault is "high" ( $\sim 50-100 \mathrm{MPa})$, consistent with worldwide in situ stress measurements in the upper few kilometers of the crust [e.g., Raleigh et al., 1972; McGarr and Gay, 1978; Brace and Kohlstedt, 1980; Pine et al., 1983; Zoback and Healy, 1984; Stock et al., 1985; Baumgärtner and Zoback, 1989; Baumgärtner et al., 1990], or whether average shear stress is "low" (comparable to average earthquake stress drops of 1-10 MPa) as implied by the absence of detectable frictionally generated heat [e.g., Brune et al., 1969; Henyey and Wasserburg, 1971; Lachenbruch and Sass, 1973, 1980]. This uncertainty has left our understanding of the fundamentals of fault mechanics on an unsatisfactory footing for over 20 years. Was one or more of the observations wrong or was the simple frictional model used to relate them flawed? Related questions include (1) Are "high-stress," experimentally based earthquake instability mechanisms (such as stickslip and time-dependent friction) applicable to earthquakes along major faults like the San Andreas [e.g., Brace and Byerlee, 1966; Byerlee, 1970; Dieterich, 1979]? (2) Do earth-

Copyright 1992 by the American Geophysical Union.

Paper number 91JB03110. 0148-0227/92/91JB-03110\$02.00 quake stress drops represent near-complete release of shear stress along the fault or only relatively minor perturbations superimposed on a high level of ambient shear? (3) If faults are weak, do they have low static strength or is strength high at the time rupture initiates but greatly diminished during sliding [e.g., McKenzie and Brune, 1972; Melosh, 1979; Lachenbruch, 1980; Raleigh and Evernden, 1981; Brune et al., 1992]? Also, to unravel processes controlling crustal deformation adjacent to transform margins (i.e., detachment faulting, block rotations, transpression and transtension), we must understand better the relative strengths of both the subvertical and subhorizontal faults that resist plate motion along plate margins [e.g., Lachenbruch and Sass, 1973, 1980, this issue; Hanks, 1977; Zoback, 1991]. Finally, to understand better the energetics and dynamics of plate motion, we need to know to what extent heuristic models of the state of stress in the lithosphere (in which the average stress level is controlled by the "high" frictional strength of the upper crust) are valid for plate boundaries [e.g., Sibson, 1982, 1983; Kirby, 1980; Chen and Molnar, 1983; Smith and Bruhn, 1984; Molnar, 1988].

The Cajon Pass borehole was drilled to a depth of $3.5 \mathrm{~km}$, about $4 \mathrm{~km}$ from the trace of the fault, in a search for mechanical or thermal effects that might shed light on these questions. One reason Cajon Pass was selected for this study is that this section of the San Andreas fault is quite late in the earthquake cycle, and thus shear stresses should be relatively high. The last major earthquake occurred in 1812 [Jacoby et al., 1988], and it offset nearby Cajon Creek about $4.5 \mathrm{~m}$ [Weldon, 1986; Sieh et al., 1989]. Judging from the geologically determined slip rate [Weldon and Sieh, 1985], the current slip deficit on this section of the fault is also about $4.5 \mathrm{~m}$. On first inspection, what was found is quite surprising: there is no evidence for either frictionally generated heat or right-lateral shear stress to a depth of $3.5 \mathrm{~km}$ [Lachenbruch and Sass, this issue; Zoback and Healy, this issue]. In other words, there is neither a thermal nor mechanical indication that a major, active plate boundary fault is only $\mathbf{4} \mathrm{km}$ away. On closer inspection, this information has provided substantial insight: First, the absence of a thermal effect supported the previous conclusions (observation 3 cited above) based upon conductive heat flow measurements in shallow boreholes (generally less than $\sim 300 \mathrm{~m}$ deep) that implied low fault friction on the San Andreas. Second, the increase in shear stress with depth documented in the Cajon Pass borehole supports observation 1 cited above, that differential stresses (and hence maximum shear stresses) are high in some directions. However, in marked contradiction to observation 2 , the direction of high horizontal shear stress 
in the borehole is not that of the San Andreas fault [Shamir and Zoback, this issue]; no component of right-lateral shear on planes parallel to the San Andreas was observed.

The $3.5 \mathrm{~km}$ depth sampled by the Cajon Pass borehole is modest compared to the $\sim 15 \mathrm{~km}$ maximum depth of earthquakes along the San Andreas system, but it is substantially greater than depths to which previous measurements of stress $(\sim 900 \mathrm{~m})$ and heat flow $(\sim 300 \mathrm{~m})$ were made and is thus less sensitive to near-surface effects. Thus the consistency of measured heat flow in the Cajon Pass borehole with shallow measurements that were made previously both near and far from the San Andreas in this region [Lachenbruch and Sass, this issue, 1988] adds credibility to the shallow measurements and to some extent to the use of similar data to infer the magnitude of shear resistance to deformation at depth in other tectonic environments [e.g., Barr and Dahlen, 1988; Molnar and England, 1990].

Although the Cajon Pass stress measurements are a factor of 4 deeper than previous measurements along the San Andreas, it is necessary to exercise caution in discussing their implications for the large-scale seismogenic system. The measurements of stress magnitudes in the borehole indicate that the crust can support large deviatoric stress in some directions. The absence of appreciable right-lateral shear on planes parallel to the San Andreas is consistent with inferences based on regional stress patterns in central California [Zoback et al., 1987; Mount and Suppe, 1987]and suggest that the San Andreas is quite weak. Beyond these generalizations, the stress results are complicated. The mean stress orientation from 1.75 to $3.5 \mathrm{~km}$ depth is $\mathrm{N} 57^{\circ} \mathrm{E} \pm 19^{\circ}$, approximately $90^{\circ}$ from that expected for a "strong" San Andreas $\left(\sim \mathrm{N} 30^{\circ} \mathrm{W}-30^{\circ}\right.$ from the $\sim \mathrm{N} 60^{\circ} \mathrm{W}$ strike of the San Andreas). The large variability of the stress orientations $\left( \pm 19^{\circ}\right)$ within the borehole is believed to be due to interactions with secondary faults at a variety of scales [Shamir and Zoback, this issue]. However, it is unlikely that the $90^{\circ}$ discrepancy in the expected maximum compressive stress direction can be explained as a perturbation from a local earthquake because earthquake stress drops cause relatively minor stress rotations at depth when, as observed, the crust is strong and differential stress levels are relatively high. Thus the Cajon Pass stress orientation data show a stress of the opposite sense to that required by a "strong" San Andreas. In fact, in terms of the San Andreas, the $\mathrm{N} 57^{\circ} \mathrm{E}$ average direction of maximum horizontal compression is quite surprising as it results in sufficient left-lateral shear on planes subparallel to the San Andreas to cause left-lateral strike-slip motion in accordance with Byerlee's law [Zoback and Healy, this issue]. Nevertheless, as surprising as this is, the observed stress orientation is consistent with Quaternary age left-lateral slip on the Cleghorn fault that parallels the San Andreas in the vicinity of the drill site [Meisling and Weldon, 1982; Weldon, 1986; R. J. Weldon et al., Neotectonics of the Silverwood Lake area, San Bernadino County, unpublished report to California Department of Water Resources, 1981]. Although the origin of this stress field is not yet well understood, Saucier et al. [this issue] can theoretically model the orientation of principal stresses in the vicinity of Cajon Pass as the result of slip along an undulatory, frictionless right-lateral strike-slip San Andreas. Both Shamir and Zoback [this issue] and Saucier et al. [this issue] show that the slip in the 1857 Fort Tejon earthquake had very little effect on the state of stress at Cajon Pass. Liu and
Zoback [this issue] developed a model for computing the effects of three-dimensional topography on in situ stress to demonstrate that the weight of the San Gabriel and San Bernandino mountains have negligible effect on the state of stress at depth at the Cajon Pass site.

A brief history and description of the Cajon Pass project were presented by Zoback et al. [1988] as an overview to a special issue of Geophysical Research Letters $(15(9), 1988)$ which contained 34 papers on preliminary scientific results of the first phase of the project. Operational aspects of the project are discussed in detail by Wicklund et al. [1990]. The papers presented in this special section of the Journal of Geophysical Research report some of the principal scientific findings from the Cajon Pass Scientific Drilling Project. A number of papers deal with the issues of fractures and rock physics. Blenkinsop and Sibson [this issue] and Vernik and Nur [this issue] address microscopic fracturing, the occurrence of ubiquitous zeolites, and other alteration minerals and their effects on rock properties. Morrow and Byerlee [this issue] specifically discuss the extremely low permeability of core samples from the borehole in terms of the effects of the alteration minerals in the microcracks. Barton and Zoback [this issue] discuss the statistical distribution of macroscopic fractures in the borehole and point out their lack of obvious relation to the current stress field. Miller and Weldon [this issue] discuss aspects of some of the faulting in the site area and Pratson et al. [this issue] discuss the geologic column in the context of a new geochemical classification system for igneous rocks based on geochemical logging techniques. In addition to the papers cited above on heat flow and stress, there are a number of others that directly bear on the interpretation of data from the borehole. Sass et al. [this issue] address determination of heat flow in a thermally noisy environment and experimental methods associated with determination of temperature-dependent thermal conductivity and the importance of conductivity anisotropy. Torgerson and Clarke [this issue] analyze radon and fluid chemistry and provide additional evidence for the absence of significant convective heat transport. Vernik and Zoback [this issue] demonstrated that estimates of the magnitude of maximum horizontal stress could be obtained from analysis of the well bore breakouts in conjunction with rock strength and least horizontal stress estimates from hydraulic fracturing. The $1988 \mathrm{GRL}$ issue covered subjects such as regional and site geology and pore fluid chemistry which are not discussed at length in the papers presented here. Extensive work of L. Silver and E. James on the geochemistry and isotropic composition of the diverse suite of crystalline rocks encountered in the borehole (and the interpretation of these data in a regional context) is currently in preparation and will be published in the future. The same is true of the analysis of vertical seismic profiling data collected in the borehole.

Viewed broadly, the principal Cajon Pass findings suggest a very weak San Andreas that moves in response to small resolved shear stress, embedded in rock that is generally strong (i.e., obeys Byerlee's law). If this is correct, the key question is no longer whether the San Andreas is weak, but why is it weak? New hypotheses have been proposed to explain fault weakness [e.g., Scholz, 1989; Rice, 1992; Byerlee, 1990; Heaton, 1990; Brune et al., 1991); their validation might ultimately require sampling and in situ observations at seismogenic depths in active fault zones. In general, the strong crust/weak fault framework is leading to new ideas on 
the meaning of crustal strength, the geologic evolution of weak faults and their implications for the balance of crustal forces. This new perspective is prompting reexamination of how we view the physics of faulting and the mechanics of deformation along major strike-slip plate boundary faults in the continents and oceans.

Acknowledgments. Financial support and encouragement of the National Science Foundation's Continental Lithosphere Program, the U.S. Geological Survey's Deep Crustal Studies Program, the Department of Energy's Basic Energy Sciences Program, and the sponsors of the Stanford Rock and Borehole Geophysics Project are gratefully acknowledged. We thank Lee Silver, Tom Henyey, and Wayne Thatcher for helping to coordinate the overall program of scientific measurements. The scientific measurements planned at the inception of this project were carried out with near total success and on budget, despite a myriad of technical difficulties. For this we have to thank our many colleagues and especially Bob Johnson, chief drilling engineer for DOSECC. Lee Silver and Eric James deserve special thanks for providing continuous on-site scientific supervision, coordinating and supervising on-site core handling operations and performing the difficult task of real-time evaluation of the core and cuttings. The U.S. Geological Survey's on-site core handling team did an excellent job. To date, over 1500 rock samples have been distributed to scientists in 14 laboratories. We wish to especially thank Wayne Campbell and Francis Gay. We also thank Gregory Beroza, Stephen Hickman, Art McGarr, George Thompson, and Mary Lou Zoback for their suggestions about these introductory comments.

\section{REFERENCES}

Barr, T. D., and F. A. Dahlen, Thermodynamic efficiency of brittle frictional mountain building, Science, 242, 749-752, 1988.

Barton, C. A., and M. D. Zoback, Self-similar distribution and properties of macroscopic fractures at depth in crystalline rock in the Cajon Pass scientific drill hole, J. Geophys. Res., this issue.

Baumgärtner, J., and M. D. Zoback, Interpretation of hydraulic fracturing pressure-time records using interactive analysis methods, Int. J. Rock Mech. Min. Sci., 26, 461-470, 1989.

Baumgärtner, J., F. Rummel, and M. D. Zoback, Hydraulic fracturing in situ stress measurements to $3 \mathrm{~km}$ depth in the KTB pilot hole VB: A summary of a preliminary data evaluation, KTB Rep. 90-6a, pp. 353-400, NLfB, Hannover, Germany, 1990.

Blenkinsop, T. G., and R. H. Sibson, Aseismic fracturing and cataclasis involving reaction softening within core material from the Cajon Pass drill hole, J. Geophys. Res., this issue.

Brace, W. F., and J. D. Byerlee, Stick-slip as a mechanism for earthquakes, Science, 153, 990-992, 1966.

Brace, W. F., and D. L. Kohlstedt, Limits on lithospheric stress imposed on laboratory experiments, J. Geophys. Res., 85, 62486252,1980

Brune, J. N., T. L.Henyey, and R. F. Roy, Heat flow, stress, and rate of slip along the San Andreas fault, California, J. Geophys. Res., 74, 3821-3827, 1969.

Brune, J. N., S. Brown, and P. A. Johnson, Rupture mechanism and interface separation in foam rubber models of earthquakes: A possible solution to the heat flow paradox and the paradox of large overthrusts, Tectonophysics, in press, 1992.

Byerlee, J. D., The mechanics of stick-slip, Tectonophysics, 9, 475-486, 1970.

Byerlee, J. D., Friction of rocks, Pure Appl. Geophys., 116, 615-629, 1978.

Byerlee, J. D., Friction, overpressure and fault normal compression, Geophys. Res. Lett., 17, 2109-2112, 1990.

Chen, W. P., and P. Molnar, Focal depths of intracontinental and intraplate earthquakes and their implications for the thermal and mechanical properties of the lithosphere, J. Geophys. Res., 88, $4183-4214,1983$.

Dieterich, J., Modeling of rock friction, 1, Experimental results and constitutive equations, J. Geophys. Res., 84, 2161-2168, 1979.

Hanks, T. C., Earthquake stress drops, ambient tectonic stresses and stresses that drive plate motions, Pure Appl. Geophys., 115, $441-458,1977$.
Heaton, T. H., Evidence for and implications of self-healing pulses of slip in earthquake rupture, Phys. Earth Planet. Inter., 64, 1-20, 1990.

Henyey, T. C., and G. J. Wasserburg, Heat flow near strike-slip faults in California, J. Geophys. Res., 76, 7924-7946, 1971.

Jacoby, G. C., P. R. Shepard, and K. E. Sieh, Irregular recurrence of large earthquakes along the San Andreas fault: Evidence from trees, Science, 24I, 196-199, 1988.

Jaeger, J. C., and N. G. W. Cook, Fundamentals of Rock Mechanics, 515 pp., Chapman and Hall, London, 1971.

Kirby, S., Tectonic stresses in the lithosphere: Constraints provided by the experimental deformation of rocks, J. Geophys. Res., 85, 6353-6363, 1980.

Lachenbruch, A. H., Frictional heating, fluid pressure and the resistance to fault motion, J. Geophys. Res., 85, 6097-6112, 1980.

Lachenbruch, A. H., and J. H. Sass, Thermo-mechanical aspects of the San Andreas fault system, in Proceedings of the Conference on Tectonic Problems of the San Andreas Fault System, edited by R. L. Kovach and A. Nur, pp. 192-205, Stanford University Press, Palo Alto, Calif., 1973.

Lachenbruch, A. H., and J. H. Sass, Heat flow and energetics of the San Andreas fault zone, J. Geophys. Res., 85, 6185-6223, 1980. (Corrections to "Heat flow and energetics of the San Andreas fault zone" and some additional comments on the relation between fault friction and observed heat flow, J. Geophys. Res., 86, 7171-7172, 1981.)

Lachenbruch, A. H., and J. H. Sass, The stress heat-flow paradox and preliminary thermal results from Cajon Pass, Geophys. Res. Lett., 15, 981-984, 1988.

Lachenbruch, A. H., and J. H. Sass, Heat flow from Cajon Pass: Fault strength and tectonic implications, J. Geophys. Res., this issue.

Liu, L., and M. D. Zoback, The effect of topography on the state of stress in the crust: Application to the site of the Cajon Pass scientific drilling project, J. Geophys. Res., this issue.

McGarr, A., and N. C. Gay, State of stress in the earth's crust, Annu. Rev. Earth Planet. Sci., 6, 405-436, 1978.

McGarr, A., M. D. Zoback, and T. C. Hanks, Implications of an elastic analysis of in situ stress measurements near the San Andreas fault, J. Geophys. Res., 87, 7797-7806, 1982.

McKenzie, D., and J. N. Brune, Melting on fault planes during large earthquakes, Geophys. J. R. Astron. Soc., 29, 65-78, 1972.

Meisling, K. E., and R. J. Weldon II, Slip-rate, offset, and history of the Cleghorn fault, western San Bernadino Mountains, southern California, Geol. Soc. Am. Abstr. Programs, 11, 215, 1982.

Melosh, H. J., Acoustic fluidization: A new geological process, $J$. Geophys. Res., 84, 7513-7520, 1979.

Miller, M. G., and R. J. Weldon, A lateral ramp origin for the north trending segment of the Squaw Peak fault, Cajon Pass, California, J. Geophys. Res., this issue.

Molnar, P., Continental tectonics in the aftermath of plate tectonics, Nature, 335, 131-137, 1988.

Molnar, P., and P. England, Temperatures, heat flux and frictional stress near major thrust faults, J. Geophys. Res., 95, 4833-4856, 1990.

Morrow, C. A., and J. D. Byerlee, Permeability of core samples from Cajon Pass scientific drill hole: Results from 2100 to $3500 \mathrm{~m}$ depth, J. Geophys. Res., this issue.

Mount, V. S., and J. Suppe, State of stress near the San Andreas fault: Implications for wrench tectonics, Geology, 15, 1143-1146, 1987.

Pine, R. J., P. Ledingham, and C. M. Merrifield, In situ stress measurement in the Carnmenellis granite, II, Hydrofracture tests at Rosemanowes Quarry to depths of $2000 \mathrm{~m}$, Int. J. Rock Mech. Min. Sci., 20, 63-72, 1983.

Pratson, E., R. N. Anderson, R. E. Dove, M. Lyle, L. T. Silver, E. W. James, and B. W. Chapple, Geochemical logging in the Cajon Pass drill hole and its application to a new oxide, igneous rock classification scheme, $J$. of Geophys. Res., this issue.

Raleigh, C. B., and J. Evernden, Case for low deviatoric stress in the lithosphere, in Mechanical Behavior of Crustal Rocks, Geophys. Monogr. Ser., vol. 24, edited by N. L. Carter et al., pp. 173-186, 24, AGU, Washington, D. C., 1981.

Raleigh, C. B., J. H. Healy, and J. D. Bredehoeft, Faulting and crustal stress at Rangely, Colorado, in Flow and Fracture of 
Rocks, Geophys. Monogr. Ser., vol. 16, edited by H. C. Heard et al., pp. 275-284, AGU, Washington, D. C., 1972.

Rice, J. R., Fault stress states, pore pressure distributions, and the weakness of the San Andreas fault, in Earthquake Mechanisms, Rock Deformation, and Transport Properties of Rocks: A Symposium in Honor of W. R. Brace, edited by B. Evans and T.-F. Wong, Academic, San Diego, Calif., in press, 1992.

Sass, J. H., A. H. Lachenbruch, T. H. Moses, Jr., and P. Morgan, Heat flow from a scientific research well at Cajon Pass, California, J. Geophys. Res., this issue.

Saucier, F. J., E. D. Humphreys, and R. J. Weldon II, Stress near geometrically complex strike-slip faults: Application to the San Andreas fault at Cajon Pass, southern California, J. Geophys. Res., this issue.

Scholz, C. H., Mechanics of faulting, Annu. Rev. Earth Plaent. Sci., 17, 309-334, 1989.

Shamir, G., and M. D. Zoback, Stress orientation profile to $3.5 \mathrm{~km}$ depth near the San Andreas fault at Cajon Pass, California, $J$. Geophys. Res., this issue.

Sibson, R. H., Fault zone models, heat flow, and the depth distribution of earthquakes in the continental crust of the United States, Bull. Seismol. Soc. Am., 72, 151-163, 1982.

Sibson, R. H., Continental fault structure and the shallow earthquake source, J. Geol. Soc. London, 140, 741-767, 1983.

Sieh, K., M. Stuiver, and D. Brillinger, A more precise chronology of earthquakes produced by the San Andreas fault in southern California, J. Geophys. Res., 94, 603-623, 1989.

Smith, R. B., and R. L. Bruhn, Intraplate extensional tectonics of the eastern Basin-Range: Inferences on structural style from seismic reflection data, regional tectonics, and thermalmechanical models of brittle-ductile transition, J. Geophys. Res. 89, 5733-5762, 1984.

Stock, J. M., J. H. Healy, S. H. Hickman, and M. D. Zoback, Hydraulic fracturing stress measurements at Yucca Mountain, Nevada, and the relationship to the regional stress field, $J$. Geophys. Res., 90, 8691-8706, 1985.

Torgerson, T., and W. B. Clarke, Geochemical constraints on formation fluid ages, hydrothermal heat flux, and crustal mass transport mechanisms at Cajon Pass, J. Geophys. Res., this issue.

Vernik, L., and A. Nur, Petrophysical analysis of the Cajon Pass well: Implications for fluid flow and seismic studies in continental crust, J. Geophys. Res., this issue.
Vernik, L., and M. D. Zoback, Estimation of the maximum horizontal principal stress magnitude from stress-induced well bore breakouts in the Cajon Pass scientific research borehole, $J$. Geophys. Res., this issue.

Weldon, R. J., The late Cenozoic geology of Cajon Pass: Implications for tectonics and sedimentation along the San Andreas fault, Ph.D. thesis, 400 pp., Calif. Inst. of Technol., Pasadena, 1986.

Weldon, R. J., and K. E. Sieh, Holocene rate of slip and tentative recurrence interval for large earthquakes on the San Andreas fault, Cajon Pass, southern California, Geol. Soc. Am. Bull., 96, 793-812, 1985.

Weldon, R. J., and J. E. Springer, Active faulting near the Cajon Pass well, southern California: Implications of the stress orientation near the San Andreas fault, Geophys. Res. Lett., 15, 993-996, 1988.

Wicklund, A. P., R. S. Andrews, G. A. Barber, and R. J. Johnson, Cajon Pass scientific drilling project: Drilling overview, in SuperDeep Continental Drilling and Deep Geophysical Sounding, edited by K. Fuchs, Y. A. Kozlovsky, A. J. Krivtsov and M. D. Zoback, pp. 40-56, Springer-Verlag, New York, 1990.

Zoback, M. D., State of stress and crustal deformation along weak transform faults, in Tectonic Stress in the Lithosphere, pp. 141-150, Royal Society, London, 1991.

Zoback, M. D., and J. H. Healy, Friction, faulting and in situ stress, Ann. Geophys., 2, 689-698, 1984.

Zoback, M. D., and J. H. Healy, In situ stress measurements to 3.5 km depth in the Cajon Pass scientific research borehole: Implications for the mechanics of crustal faulting, J. Geophys. Res., this issue.

Zoback, M. D., et al., New evidence on the state of stress of the San Andreas fault system, Science, 238, 1105-1111, 1987.

Zoback, M. D., L. T. Silver, T. Henyey, and W. Thatcher, The Cajon Pass scientific drilling project: Overview of phase I, Geophys. Res. Lett., 15, 933-936, 1988.

A. H. Lachenbruch, U.S. Geological Survey, 345 Middlefield Road, MS 977, Menlo Park, CA 94025.

M. D. Zoback, Department of Geophysics, Stanford University, Stanford, CA 94305.

(Received December 13, 1991; accepted December 13,1991.) 